\title{
Possessors as Subjects and Objects: Different Ways of Possessors Act as Subject and Object Arguments on Verbs in the Languages of Papua
}

\author{
Yusuf Sawaki
}

\author{
Pusbadaya \& CELD, UNIPA Manokwari, Papua Barat \\ *Corresponding author.Email: ysawaki@fulbrightmail.org
}

\begin{abstract}
This paper surveys a morpho-syntactic construction in which the possessors of possessive morphology on nouns are used to index subject and object arguments on verbs in some languages in Papua. Naturally, possessive morphology treats person markers as possessors in ownership or any kinds of relations such as my book, his house and my friend in English. Thus, the possessor marker in this construction is restricted to the nominal possessive construction. In some languages in Papua, the possessor of the possessive morphology is not just restricted to the nominal possessive construction possessors. It may also act as subject and object markers on verbs. This survey found that possessors acting as subject markers are common among Austronesian languages such as Wooi Sawaki [1], Biak Heuvel [2] and Mofu [3], Wamensa/Wandamen Gasser [4], and Matbat (Remijsen 2010). As for Papuan languages such as Yali Sawaki [5], Lower Grand Valley Dani (Bromley [6], Sawaki [5]), Hatam (Reesink [7]), Yaben (Sawaki [8]), the possessor marker can function as subject and/or object on verbs. The survey found out that only certain verb classes can take the possessor as subject and/or object markers. Both Papuan and Austronesian languages tend to have the possessor-subject on the inner-psychological or cognitive verbs. Further, Papuan languages also operate the possessor as the object agreement on transitive verb constructions. In summary, the possessor that is mainly restricted semantically to nominal possessive constructions extends its semantic and morpho-syntactic function to the subject and/or object arguments on verbal constructions in Austronesian and Papuan languages in Papua.
\end{abstract}

Keywords: Possessor, functional roles, subject and object, inner-psychological verbs, languages of Papua

\section{INTRODUCTION}

One of the grammatical features commonly found in languages of Papua, both Austronesian and Papuan languages, is a complex system of possessive constructions. Many studies such as Bromley [6], Reesink [7], Heuvel [2], Sawaki [5], [1], [8], Donohue \& Schapper [9], Mofu [3] has shown such a complex grammatical feature. Naturally, possessive constructions belong to the noun class feature, by which they mark a possessive relation or any kind of relation to a noun such as my book, his house and my friend in English. Thus, the possessor marker in this construction is mainly restricted to the nominal possessive construction.

This study is a typological study in which I use data from languages of different groups across Papua to investigate a particular linguistic feature, i.e. different functional roles of possessor across word classes and to investigate their common features. This study includes 8 languages from three different language groups.

\section{POSSESSION OF NOUNS}

Semantically, possession of nouns shows any kind of relation between a possessor and a possessed noun. Structurally, the relation of the possessor and the possessed noun is marked by certain kinds of morphosyntactic features. The morphosyntactic features of possession of nouns range from simple to complex across languages of Papua. The followings are some constructions in some languages of Papua.

Lower Grand Valley Dani [6]:

304-305)
1) n-oppase
2) in-asu 
1sg-father

'my father'

3pl-net'

'their net'

Yeben [8])

3) neng-kaka

1sg-aunt

'my aunt

Matbat (Remijsen 2010)

5) fa-ng husband-1sg

'my husband'
4) nani-noba

1pl-house

'our house'

6) $b a-n g$ shoulder-1sg 'my shoulder'

There are also variations of possessive constructions such as:

7) пе-тu manu

poss-2sg house 'your house' (Wooi - Sawaki [1])

8) hentapumi

he-tapu-m-i

3pl-PSRgrantparent-PSR.NSG-PSS.SG

'their grantparent' (Wooi-Sawaki [1])

9) nani wawo

our father

'our father' (Yaben - Sawaki [8])

10) di-cig ni-de micim

1 sg-father 3sg-POS spear

'my father's spear'(Hatam-Reesink

Different kinds of possessive constructions showing the relation between the possessor and the possessed noun indicate alienable $(1,3,5,6,8)$ and inalienable $(2,4,7)$ relations and example 10 shows a combination of both alienable and inalienable relations. In example 9, the possessor and the possessed noun is juxtaposed. Alienable possessions are always marked on body parts, kinship terms, and some culturally related nouns. Inalienable possessions refer to any kinds of common nouns that are not counted as those that belong to the alienable possession.

Common terms used to describe these constructions are alienable vs. inalienable possessions [6]; [2]; [3] and direct and indirect possessions [10], [1].

\section{FUNCTIONAL ROLES OF THE POSSESSOR}

In some languages of Papua, the functional roles of the possessor are shown in this functional hierarchy:

\section{POSSESSOR $>$ SUBJECT $\{$ ACT/AGT/EXPR $\}>$ OBJECT $\{$ PAT/EXPR $\}$}

The possessor functions as an object are the lowest in the hierarchy meaning that only some languages (i.e. TNG) apply for this functional role and only for a certain type of verbs, which is the transitive verbs. All languages in the survey apply the possessor as the subject markers in different verb predicates.

The followings are languages that apply some functional roles of possessor markers in the verbal predicates.

\begin{tabular}{|l|l|l|l|l|}
\hline $\begin{array}{c}\text { Languag } \\
\text { e }\end{array}$ & Family & \multicolumn{3}{|c|}{ Functional roles } \\
\hline & & $\begin{array}{c}\text { Possesso } \\
\text { r }\end{array}$ & Sbj & Obj \\
\hline LGVD & TNG & Yes & Yes & Yes \\
\hline Yali & TNG & Yes & Yes & Yes \\
\hline Yaben & TNG & Yes & Yes & - \\
\hline Hatam & WP & Yes & Yes & - \\
\hline Wooi & $\begin{array}{l}\text { Austronesi } \\
\text { an }\end{array}$ & Yes & Yes & - \\
\hline Matbat & $\begin{array}{l}\text { Austronesi } \\
\text { an }\end{array}$ & Yes & Yes & - \\
\hline $\begin{array}{l}\text { Wandam } \\
\text { en }\end{array}$ & $\begin{array}{l}\text { Austronesi } \\
\text { an }\end{array}$ & Yes & Yes & - \\
\hline Biak & $\begin{array}{l}\text { Austronesi } \\
\text { an }\end{array}$ & Yes & Yes & - \\
\hline
\end{tabular}

The followings are some examples:

11) $\boldsymbol{n}$-inom 1sg-together

(Bromley [6])

'together with me'

12) $\boldsymbol{n}$-elu

(Sawaki [1])

1sg-know

'I know'

13) n-athe 1sg-hit.PST.3sg

'he hit me'

In Lower Grand Valley Dani, the same possessor marker on nouns marks the prefixed-subject on verbs as in 11 and 12 and the object of a verb as in 13. Yali [5]) also have the same features as Lower Grand Valley Dani [6]; [5] where the possessor functions as the subject and the object in different types of verbs.

In Hatam, Reesink [7] mentions that verbs of emotion take the inalienable noun construction. The possessor marker functions as the subject marker in emotion verbs. 
14) Leu

from

nani

nyeni ni-ngon dut

you

we

1EXC-heart

ni-ndig bibor

'For we appreciate you very much.'

15) Ni-ngon sibui sut gi po

3SG-heart twist about NOM ANA

da dihig

pia

I 1SG-ask

QUOT

'She was angry that I asked her...'

Likewise, Yaben Mayor [11] also has the same construction as Hatam by which the possessor functions as subject marker on the emotion and state verbal predicates.

16) Ne e-sepya ne-netoro suri

$1 \mathrm{sg} 2$ sg-see 1 sg-stomach very

'I saw you so I am very happy'

17) ne-suburu beage

1sg-neck manner

'I think in this way'

In some Austronesian languages such as Biak (Heuvel [2]), Wandamen (Gasser, [10], pc), Matbat (Remijsen 2010), Wooi (Sawaki [1]) also have the construction in which the possessor functions as the subject marker on sensory and emotion verbs.

18) Nusnesna

Nu-sne-s-na

1DU.EXC-belly-NSG.AN-3PL.INAN

nro $i$

n-ro

3.PL.INAN-LOC 3SG

'The two of us love him.' (Lit: 'Our bellies are with him.') [2])

19) Yau i-sane-vesie

I 1sg.PSR-stomach-good

y-unu karumas kopi

1SG-drink hot.water coffee

'I like to drink hot coffee' [10], pc)

20) $y a^{21} k \quad \boldsymbol{l b}^{3} \boldsymbol{\eta}$ - $\boldsymbol{d e ^ { I 2 1 }} \quad y a^{21} w a$

$1 \mathrm{~s} \quad$ want:1s-sick $2 \mathrm{~s}$

'I hate you' (Matbat, Remijsen 2006)

21) $y a^{21} k \quad \boldsymbol{b}^{3} \boldsymbol{\eta} \quad \boldsymbol{i}-f^{3}$

1s want:1s 3s-good

'I am happy' (Matbat, Remijsen 2006)

22) Masaneho

ma-hane-ho

1PL.EXC.PSR-stomach-HO

$\begin{array}{ll}\text { mantamami } & \text { kong } \\ \text { ma-tama-m-i } & \text { kong }\end{array}$

1PL.EXC.PSR-father-NSG-SG COM

\section{masinyami \\ haru \\ ma-hinya-m-i haru \\ 1PL.EXC.PSR-mother-NSG-SG 3DU \\ 'We love/remember our father and mother.' \\ [1] \\ 4. TYPES OF VERBS OF VERBS TAKING THE POSSESSOR AS THE SUBJECT AND OBJECT MARKERS}

Verbs that can take the possessor as a subject marker or object marker semantically range from action verbs to more stative verbs such as state, emotion, cognitive, and sensory verbs. The possessor functioning as the object only occurs with transitive active action verbs as in LGVD and Yali. Other types of verbs which are classified as stative verbs (state, emotion, cognitive, sensory verbs) take the possessor functioning only as the subject.

\begin{tabular}{|l|l|l|l|l|l|}
\hline \multirow{2}{*}{ Languages } & \multicolumn{5}{|c|}{$\begin{array}{r}\text { Types of verbs and functional } \\
\text { roles of the possessor }\end{array}$} \\
\cline { 2 - 6 } & ACT & \multicolumn{5}{|c|}{ STAT } \\
\cline { 2 - 6 } & Act & state & emo & cog & sens \\
\hline $\begin{array}{l}\text { LGVD } \\
\text { (TNG) }\end{array}$ & obj & sbj & sbj & sbj & sbj \\
\hline $\begin{array}{l}\text { Yali } \\
\text { (TNG) }\end{array}$ & obj & sbj & sbj & sbj & sbj \\
\hline $\begin{array}{l}\text { Yaben } \\
\text { (TNG) }\end{array}$ & - & - & sbj & - & sbj \\
\hline $\begin{array}{l}\text { Hatam } \\
\text { (WP) }\end{array}$ & - & - & sbj & - & - \\
\hline Wooi (AN) & - & - & - & - & sbj \\
\hline Biak (AN) & - & - & - & - & sbj \\
\hline $\begin{array}{l}\text { Wandamen } \\
\text { (AN) }\end{array}$ & - & - & - & - & sbj \\
\hline $\begin{array}{l}\text { Matbat } \\
\text { (AN) }\end{array}$ & - & - & - & - & sbj \\
\hline
\end{tabular}

\section{SEMANTIC ROLES OF THE POSSESSOR}

There are two ways in interpreting semantic roles of the possessor:

a) active vs stative roles of the actor whether as the subject or object, and

b) inner-psychological events that are seen as parts of body-part activities.

Languages of Papua distinguish verbs into active vs. stative categories. In regards to person markings on verbs, the more stative is a verb; it tends to take the possessor-possessed noun construction in its grammatical relation (subject vs. object). Note that the 'stative' notion refers to any kinds of verbs that indicate inner-psychological or cognitive expressions 
of human activities. Inner-psychological or cognitive expressions of human activities are categorized as inner-human possession. Thus, a verb that structurally represents such an expression must take possessive construction as that of possessive of human body parts.

\section{CONCLUSION}

Different ways of the possessors of possessor morphology behave as the subject and object arguments on different types of verbal predicates are predictably common across languages in Papua, regardless of their linguistic affiliations. It is shown that the linguistic features are found across language groups whether they are Papuan or Austronesian languages. Where do these features come from? My preliminary argumentation states that these features derive from Papuan substrate where the distribution of the functional roles of the possessor is based on the semantic definition and are found across different types of verbs in different languages regardless of their genetic groupings. This feature is still found in other languages (Austronesian and Papuan languages of the Bird's Head region). This could be a prototypical areal feature of the languages of Papua. Further investigation is needed by looking at more data from languages representing different language groups.

\section{REFERENCES}

[1] Sawaki, Yusuf. (2016). A grammar of Wooi: an Austronesian language of Yapen Island, Western New Guinea. A doctoral thesis. Canberra. The Australian National University.

[2] Van den Heuvel, Wilco. (2006). Biak: Description of an Austronesian language of Papua. Ph.D. thesis, Amsterdam. Vrije Universiteit.

[3] Mofu, Suriel S. (2008). Biak Morphosyntax. A doctoral thesis. Oxford. University of Oxford.

[4] Gasser, Emily Anne. (2015). The development of verbal infixation in Cenderawasih Bay. In Ross, Malcolm and Arka, I Wayan (Eds.). Language change in Austronesian languages: Papers from 12-ICAL(3). 1-17. Canberra. Pacific Linguistics.

[5] Sawaki, Yusuf. (2008). Person marking system in Dani languages. In Linguistik Indonesia, 129150.

[6] Bromley, Myron. (1972). The grammar of Lwer Grand Valley Dani in discourse perspective. Yale University.
[7] Reesink, Ger. A Grammar of Hatam: Bird's Head Peninsula, Irian Jaya. Pacific Linguistics. ANU. Canberra.

[8] Sawaki, Yusuf. (2019). Yaben: a Papuan of Trans New Guinea language of the south Bird's Head of New Guinea. CELD-UNIPA. Manokwari.

[9] Donohue, Mark \& Antoinette Schapper. (2008). Whence the Austronesian indirect possession construction? In Oceanic Linguistics, 47(2). 316327.

[10] Gasser, Emily Anne. (2014). Windesi Wamesa Morphophonology. A doctoral dissertation. New Heaven. Yale University.

[11] Mayor, Infak. (2019). Possessive constructions in Yaben. S1 Skripsi. Faculty of Letters and Culture. University of Papua. Manokwari. 